MILOŠ POLIAK, Ph.D.

E-mail: milos.poliak@fpedas.uniza.sk

University of Žilina, Faculty of Operation and Economics

of Transport and Communications

Univerzitná 1, 02601 Žilina, Slovak Republic
Transportation Economy

Preliminary Communication

Accepted: Nov. 4, 2010

Approved: Dec. 20, 2011

\title{
IMPACT OF ROAD NETWORK CHARGING SYSTEM ON PRICING FOR GENERAL CARGO TRANSPORTATION
}

\begin{abstract}
The paper defines the problem of pricing in general cargo by impact of toll in the first section. Different usage of a vehicle in individual transportation causes that it is not possible to calculate the toll uniformly for every cargo by constant price for the customer in the same transportation. The next part analyses the existing processes of the toll share for general transport described in Austria, Bohemia and Germany. None of the processes can be used for another state in general. The rest is a draft of the new method of toll share for general transport determination.
\end{abstract}

\section{KEY WORDS}

transportation, pricing, cargo, toll, road

\section{INTRODUCTION}

The European Union member countries are gradually changing to the performance of charging road network, which replaces the fee for its usage by highway stickers. From the countries that recently introduced electronic toll collection, for example, Germany, Austria, the Czech Republic and the Slovak Republic can be mentioned, whereby the change to the system relies on a fairer system of charging for the usage of the road network in which each carrier will bear the fees that are dependent on the actually travelled distance [1]. For carriers, the introduction of the performance fee by charging toll brings an increase in the extent of charging and thereby increases the cost. For example, in the Slovak Republic the introduction of the performance fee of the road network has increased the extent of the charged road network from $715 \mathrm{~km}$ in 2009 to $2,400 \mathrm{~km}$ in $2010^{1}$. Considering that the increasing costs of using the road network cannot be paid from the reserves carriers, it is necessary to transfer these costs into the consumers' price ${ }^{2}$. From the position of the carrier with full truck loads it is not a problem to assign higher costs of a particular charged road network traffic and thus a particular consignment to be carried during the transport. The problem arises with general cargo (packages) that is carried during the transport by several means of transport, when the transport is mostly carried out along with other items. At present there is no single approach to the assessment of the allotment of consignments to charge a fee for the road network. Therefore, within the project Methodology for setting rates for the transport of general cargo on the territory of Slovak Republic after the introduction of electronic toll collection system a theoretical insight into these issues was developed with the recommended procedure which is applicable in each country for the introduction of a performance road charging system.

\section{PROPER PRICING SYSTEM ACCORDING TO MARKET}

The logistics technology of general cargo can be organized in different ways; the common feature being that consignments for multiple users are transported by a single means of transport [2]. The number of vehicles depends on the logistics technology which can include:

- star system of one central transit shed [3] - work technology of the system is concentrating consignments in the central transit shed (CP), which is assembled from individual collection centres (Si), which provides collection of consignments from different consignors $\left(\mathrm{O}_{\mathrm{ij}} \mathrm{i}\right.$ - is the order of the consignor, $\mathrm{j}$ - is the collection centre). After completion of items in the $\mathrm{CP}$, the consignments are distributed to individual centres (Si), followed by deliveries to individual consignees $\left(\mathrm{P}_{\mathrm{ij}} \mathrm{i}\right.$ - is the order of the consignee, $\mathrm{j}$ - is the collection centre) (Figure 1).

- system of two centraltransitsheds [4]-is used in case of higher traffic flows between the two territories. The carriage between two central transit sheds is carried out by the vehicles of greater transportation capacity. The collection and the distribution of the central transit sheds is implemented as in case of a star system of one central transit shed (Figure 2). 


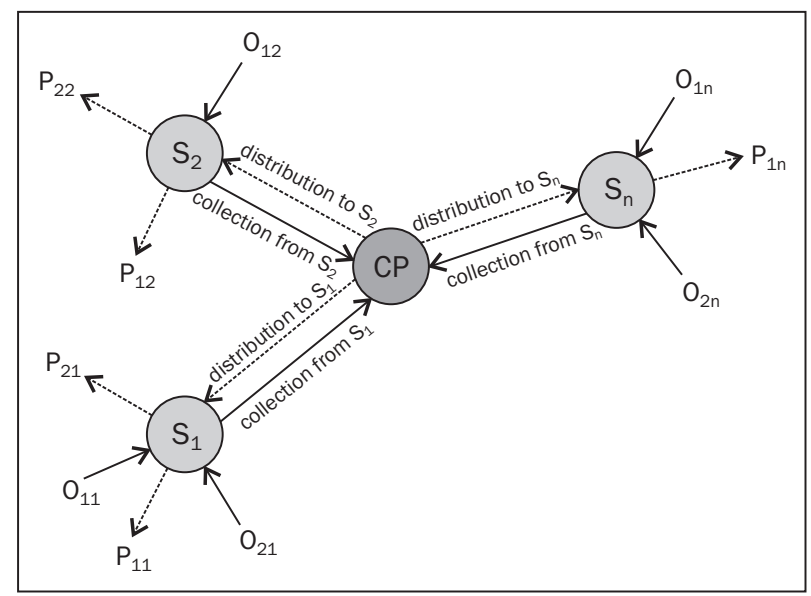

Figure 1 - Star structure of the transportation of consignments

The problem of determining the growth prices for using the road network is that the simple transfer of charges for using the road network to a particular consignment cannot provide a constant amount of the fee for the same transportation. In Figure 2 it is possible to highlight the problem of a concrete example. It is considered that the transport technology of general cargo is provided in the two days the same way. The consignments are transported in the system for multiple consignees from multiple consignors. When comparing the collection to Centre 1 (S1), on the first day the capacity of the vehicle used is $3 / 4$ (1/4 is used by the consignor of a particular consignment) The second day the capacity utilization is 50 per cent, only a half $(1 / 2)$, because on that day one consignor on the col- lection route did not send a consignment. The S1 is transporting consignments on higher capacity vehicle and they are transported to a central transit shed. By this transportation there is a different usage of the vehicle ( $2^{\text {nd }}$ day the capacity is used 100 per cent), which means that with the constant charge for the use of the road network, the allotment in the consignment would not be constant. This principle applies to the rest of the transportation.

The price changing for the customer for each transportation can be considered only in the case when the transportation were realized on the market with non-elastic demand, where the percentage change in the demand would be significantly lower than the percentage change of price [5]. The analysis of customer demand for transport services ${ }^{3}$ shows that for the same means of transport of the same consignments from the position of the carrier it is not appropriate to change the price of each transportation, because on these days it operates on the carrier market with high competitive offer of transport, causing an elastic demand for transport services.

\section{ANALYSIS OF APPROACHES TO CHARGES FOR USING ROAD NETWORK FOR THE TRANSPORTATION OF GENERAL CARGO IN SELECTED COUNTRIES}

The analysis of approaches to charges for using the charged road network for the transportation of general cargo has been prepared for Austria, Germany and for

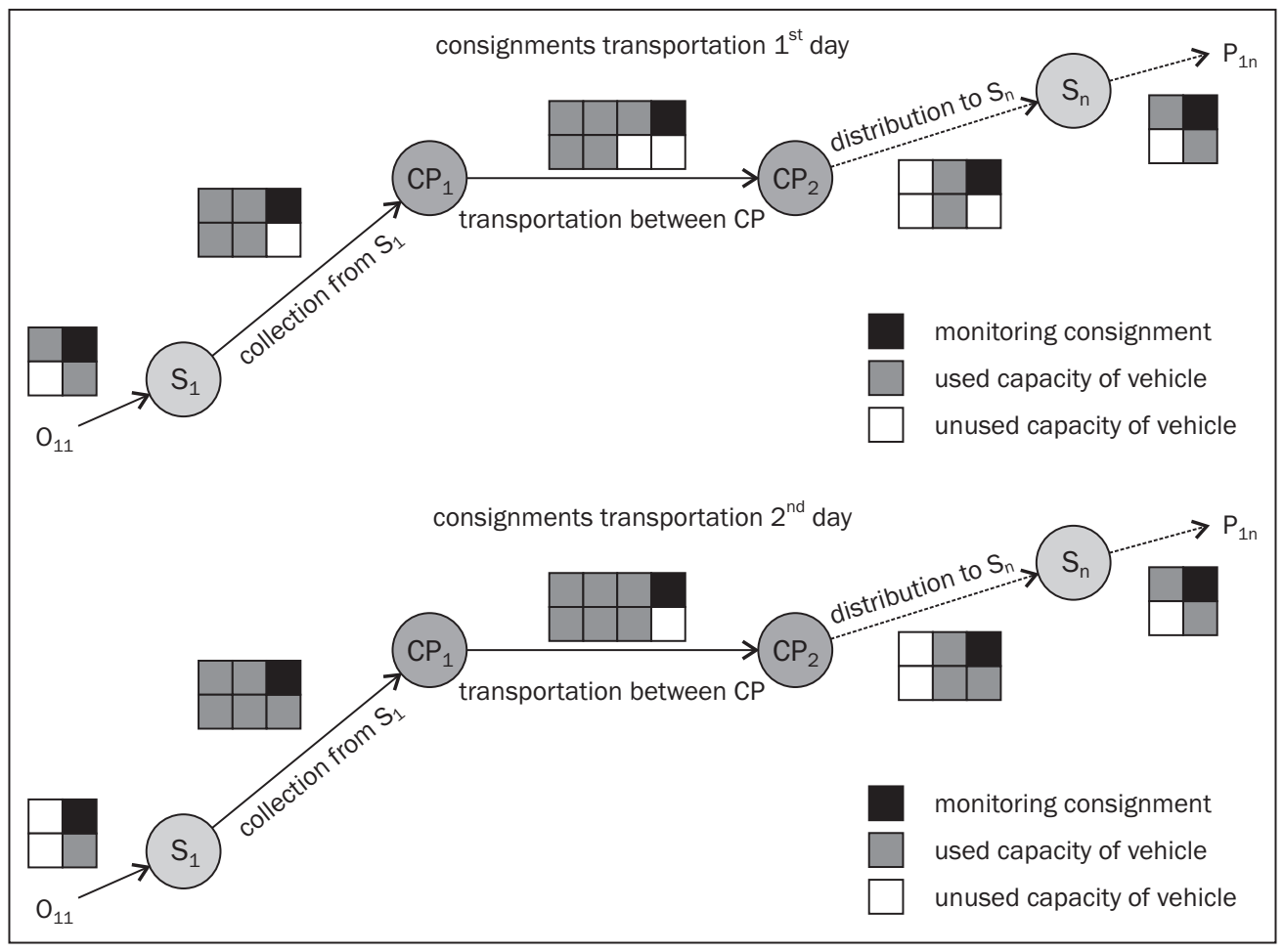

Figure 2 - Using vehicles for single transportation 
the Czech Republic. It should be noted that even in one of the analyzed countries as indicated in the following section of contribution, the price is not set for each transportation of general cargo.

\subsection{Method for calculating toll rates into the price of the transportation of consignments in Austria}

In Austria, the carrier is obliged to around $2,060 \mathrm{~km}$ of road network pay-operating toll for using the road infrastructure in the operation of vehicles with gross weight over $3.5 t^{4}$.

The toll rates for using the road network in Austria are set in accordance with the current EU legislation ${ }^{5}$ that must be incorporated in the operating tolls preference of environmentally-friendly vehicles. For this reason, since 1 January 2010 the vehicles are divided into three tariff groups, on which the amount of fee for using the road network depends (www.go-maut.at):

- tariff group A - trucks with Euro EEV emission class and Euro 6,

- tariff Group B - trucks with emission class Euro 4 and Euro 5

- tariff Group C - trucks with emission class EURO 0 to EURO 3.

The method for determining the tariff surcharge in Austria because of the introduction of electronic toll takes into account the distance of transportation and the weight of the consignment.

The consignments are divided into two groups [6]:

- weight of consignments to $2,000 \mathrm{~kg}$ - these consignments are being considered with the tariff divided into 5 zones of distance;

- weight of consignments 2,001kg and more - these consignments are being considered with the tariff divided into 8 zones.

The different distribution of tariff zones for the consignments up to and over $2,000 \mathrm{~kg}$ is based on a more detailed segmentation of the tariff distance for heavier consignments. Unlike the usage of the highway sticker (with the increasing distance the amount of administration costs decreases), with higher operating tolls in the distance, the allotment of the distance travelled along the charged road with toll increases, which implies that the costs of the toll with the increasing distance behave progressively. Therefore, for consignments of over $2,001 \mathrm{~kg}$ there are greater distance gap zones in Austria. The method used in Austria also takes into account the degree of utilization of the vehicle payload. This is an indicator which depends on many factors, such as:

- structure of carried goods,

- requirements of the consignor,

- the type of packaging,
- the underserved area,

- the season, etc.

Table 2 - Continuous vehicle occupancy for consignments from 1,375 to 3,500kg in Austria

\begin{tabular}{||c|c||}
\hline \hline Weight of consignments (kg) & Vehicle occupancy (kg) \\
\hline \hline 1,375 & 8,500 \\
\hline 1,750 & 9,500 \\
\hline 2,250 & 10,000 \\
\hline 2,750 & 11,000 \\
\hline 3,500 & 12,000 \\
\hline
\end{tabular}

Source: [6]

In Austria, for the consignments of up to $2,000 \mathrm{~kg}$ the vehicle occupancy is considered with the payload of $8,000 \mathrm{~kg}$, for consignments of over $2,000 \mathrm{~kg}$ the vehicle occupancy is considered with the payload of $12,000 \mathrm{~kg}$. Lower vehicle occupancy for consignments of up to $2,000 \mathrm{~kg}$ is based on the fact that in this weight category various consignments are carried and to occupy a vehicle with a payload of $8,000 \mathrm{~kg}$ the vehicle is usually engaged 100 per cent [6]. Therefore, to offset the transitions between consignments of up to $2,000 \mathrm{~kg}$ and over $2,000 \mathrm{~kg}$, from the weight of $1,375 \mathrm{~kg}$ and $3,500 \mathrm{~kg}$ the vehicle occupancy is continuously changing, which is shown in Table 2.

The determination of the tariff rate in Austria considers the allotment of unused travelled distance at 16 per cent; therefore, those vehicles are required to pay the toll regardless of whether the transport is with cargo or without it.

\subsection{Methodology for calculating the toll rates into the price of the transportation of consignments in Germany}

In Germany all vehicles with the gross weight exceeding 12 t are liable to operating toll, except vehicles carrying goods for exhibitions and circuses. In Germany about $12,000 \mathrm{~km}$ of roads are liable to toll with the exception of A98 highway between Laufenburg and Luttingenem and between Tiengen-west and Lauchringen 6 .

In Germany the toll is dependent on the number of vehicle axles and on the emission class of vehicle engine. The toll rates are listed in Table 3.

Table 3 - Toll rates in Germany $€ / \mathrm{km}$ excluding VAT

\begin{tabular}{||l|c|c||}
\hline $\begin{array}{c}\text { Emission class of } \\
\text { vehicle engine }\end{array}$ & $\begin{array}{c}\text { up to 3 } \\
\text { axles }\end{array}$ & $\begin{array}{c}\text { 4 and more } \\
\text { axles }\end{array}$ \\
\hline \hline Euro 0, Euro 1 and Euro 2 & 0.274 & 0.288 \\
\hline Euro 3 and Euro 2 with filter & 0.190 & 0.204 \\
\hline Euro 4 and Euro 3 with filter & 0.169 & 0.183 \\
\hline Euro 5 and EEV & 0.141 & 0.155 \\
\hline
\end{tabular}

Source: prepared on the basis of data published on www.toll-collect.de 
The method for determining the tariff surcharge for the transportation of general cargo in Germany with the influence of the introduction of operating toll divides consignments by vehicle occupancy into two groups ${ }^{7}$ :

- consignments with the weight of up to $3,000 \mathrm{~kg}$ (general cargo) - these consignments are intended for vehicle occupancy with payload of 8,000kg,

- consignments with the weight of over $3,001 \mathrm{~kg}$ (partial or completed cargo) - these consignments are intended for vehicle occupancy with payload of $12,000 \mathrm{~kg}$.

Considering that using the criteria of the number of axles, emission class of vehicle engine and the charged road network travelled distance of the vehicle it is possible to calculate the toll charges just for using of the vehicle, it means for completed consignments. For transport of general cargo and partial cargo in Germany an additional criterion is introduced, with toll charges distributed to a single consignment for each customer. As an aid in this conversion the vehicle occupancy is used by differentiating according to kilograms and filling the loading area, the socalled Lademeter ${ }^{8}$.

The starting point for the conversion of toll fee, among the consignments, is the payment of the tolls of the used vehicle. The determination of price increase to transport the consignment is as follows ${ }^{9}$ :

- Toll rates per $\mathrm{km}$ - to calculate the toll falling on truck the average toll rate of 0.124 Euro $/ \mathrm{km}$ is used. The relevant toll for the truck is based on the multiplication of this toll rate and the average class distance.

- Conversion tolls for truck for consignments - to convert the amounts of toll for truck for moving goods (consignments) is determined by the used payload, which for consignments of up to $3,000 \mathrm{~kg}$ is $8,000 \mathrm{~kg}$ and for consignments of over $3,001 \mathrm{~kg}$ is $12,000 \mathrm{~kg}$. The total toll fee for transport is determined by one kilogram of used payload of vehicle.

- Determination of levels of the distance gap - tolls paid for highway usage by trucks is being reported accurately to the kilometre. But for its further conversion to individual customers the kilometre-exact carriage of general cargo is impractical. For this reason, in Germany a fixed payment tariff has been created, which results in creating the levels of distance gap with a width of $100 \mathrm{~km}$. The toll is always converted to the level of the distance gap.

- Determination of weight categories - like the distance, to simplify the calculations and convert toll for the weight-class of consignments it is always the authoritative average weight range. However, in case of toll charges, in the table for general cargo the first weight category is different and it is used to adjust the toll to $35 \mathrm{~kg}$ of weight.

\subsection{Method for calculating the toll rates into the price of the transportation of consignments in the Czech Republic}

All vehicles with a gross weight of over 3.5 tons with $1,077 \mathrm{~km}$ of highways and motorways and $199 \mathrm{~km}$ of selected roads of Class I are subject to electronic toll in the Czech Republic ${ }^{10}$. The toll in the Czech Republic depends on the number of axles, on emission class of vehicle engine, on the used road network and on the time of vehicle operation. The toll rates are shown in Table 4.

The method for setting the toll rates for the transport of general cargo sets out the following steps in the Czech Republic [3]:

- to calculate the average toll rate for highways and motorways:

$S_{D R}=\sum_{i=1}^{n}\left(x_{i} \cdot y_{i}\right) \cdot a$

$S_{D R}$ - average toll rate for highways and motorways,

$x$ - rate tolls for highways and motorways,

$y$ - share of the fleet as percentage,

$i$ - dependence of vehicle emission standards to Euro and number of axles,

a - percentage of distance travelled on highways and motorways of the total distance travelled;

- to calculate the average toll rate for the roads of Class I:

$S_{I T}=\sum_{i=1}^{n}\left(z_{i} \cdot y_{i}\right) \cdot b$

Table 4 - Toll rates in the Czech Republic CZK/km excluding VAT

\begin{tabular}{||l|c|c|c|c|c|c||}
\hline \multicolumn{1}{|c|}{ Type of roads No. of axles } & \multicolumn{2}{c|}{ Highways and motorways } & \multicolumn{3}{c||}{ Selected roads of Class I } \\
\hline Emiss. class & 2 & 3 & $\begin{array}{c}4 \text { and } \\
\text { more }\end{array}$ & 2 & $\begin{array}{c}4 \text { and } \\
\text { more }\end{array}$ \\
\hline \hline to Euro 2 & 2.26 & 3.63 & 5.30 & 1.08 & 1.77 & 2.55 \\
\hline to Euro 2 (on Fridays from 3pm to 9pm) & 2.87 & 5.55 & 8.10 & 1.37 & 2.70 & 3.90 \\
\hline Euro 3 and more & 1.67 & 2.85 & 4.12 & 0.79 & 1.37 & 1.96 \\
\hline Euro 3 and more (on Fridays from 3pm to 9pm) & 2.12 & 4.35 & 6.30 & 1.00 & 2.10 & 3.00 \\
\hline
\end{tabular}

Source: prepared on the basis of data published on www.premid.cz 
$S_{I T}$ - average toll rate for roads of Class I,

$z$ - toll rate for the roads of Class I,

$y$ - percentage of the fleet,

$i$ - dependence of the vehicle on emission standards Euro and number of axles,

$b$ - percentage of distance travelled on toll roads of Class I of the total distance travelled;

- to calculate the total toll rate for full truck loads:

$S_{C}=S_{D R}+S_{I T}$

$\mathrm{S}_{C}$ - the overall rate of tolls;

- compilation of tariff rates depending on the weight of the general cargo and travelled distance:

tariff rates $=\frac{S_{C} \cdot l}{M} \cdot m$

$\mathrm{S}_{C}$ - total toll rate,

I - distance in $\mathrm{km}$,

M - average utilization of vehicles,

$m$ - weight of the consignment.

When drawing up the tariff rates in the Czech Republic in the application of the methodology based on the survey, which found [3]:

- average utilization of payload of vehicles is $8,211 \mathrm{~kg}$, therefore, in preparing of tariffs the utilization of payload of vehicle close to $8,000 \mathrm{~kg}$ was used,

- 75 per cent of journeys of carriers are made on the charged road network,

- toll rates are provided only for general cargo up to the weight of $3,000 \mathrm{~kg}$.

\subsection{Comparison of methods for determining the toll rates for the transportation of general cargo}

Table 5 compares the basic parameters of the methods used in Austria, Germany and in the Czech Republic for determining extra toll rates for the transport of general cargo. For each method the transport distance and weight of transported consignment are reflected, whereby in Germany and in Austria the toll rate is also dependent on the categorization of the consignment according to the weight because of the charge of payload vehicles. In Austria the payload vehicles are considered close to $12,000 \mathrm{~kg}$ in case if the weight of the consignment is higher than 2,001kg. In Germany, with the same charge the weight of the consignment of more than $3,001 \mathrm{~kg}$ is considered acceptable.

In Austria the toll fee for the transportation of general cargo depends on the average payload of vehicle use (use of payload vehicles close to 84 per cent) and in the Czech Republic it is considered with the allotment of journeys on the charged road network of the total distance travelled close to 75 per cent.

For the method of determining the toll rates for transportation of general cargo it is also important to consider the type of vehicles subject to the payment of tolls. It concerns vehicles with a gross weight exceeding 3.5 tons in Austria and in the Czech Republic, and it concerns vehicles with a gross weight exceeding 12 tons in Germany.

After the introduction of tolls in other countries, none of the methods are applicable in other countries. There are even differences among the methods of these countries themselves. The weaknesses of the methods can be summarized in the following areas:

Table 5 - Comparison of basic parameters of methodologies used in Austria, Germany and in the Czech Republic for setting toll rates for the transportation of general cargo

\begin{tabular}{|c|c|c|c|}
\hline Indicator & Austria & Germany & Czech Rep. \\
\hline Transport distance & Yes & Yes & Yes \\
\hline Weight of the consignment & Yes & Yes & Yes \\
\hline $\begin{array}{l}\text { Categorization of consignments ac- } \\
\text { cording to the weight }\end{array}$ & $\begin{array}{c}\text { Yes } \\
\text { (up to } 2,000 \text { and } \\
\text { more than } 2,001 \mathrm{~kg} \text { ) }\end{array}$ & $\begin{array}{c}\text { Yes } \\
\text { (up to } 3,000 \text { and } \\
\text { more than } 3,001 \mathrm{~kg} \text { ) }\end{array}$ & $\begin{array}{c}\text { No } \\
\text { (up to } 3,000 \mathrm{~kg} \text { ) }\end{array}$ \\
\hline Average utilization of the vehicle & $\begin{array}{l}8,000 \text { and } \\
12,000 \mathrm{~kg}\end{array}$ & $\begin{array}{l}8,000 \text { and } \\
12,000 \mathrm{~kg}\end{array}$ & $8,000 \mathrm{~kg}$ \\
\hline $\begin{array}{l}\text { Continuous utilization of the vehicle for } \\
\text { more usages of weight of the vehicle }\end{array}$ & Yes & No & - \\
\hline Taking into account the use of payload & Yes (84 per cent) & No & No \\
\hline $\begin{array}{l}\text { Taking into account more types of } \\
\text { rates for individual journeys }\end{array}$ & No & No & Yes \\
\hline $\begin{array}{l}\text { Taking into account the allotment } \\
\text { of journeys on charged roads }\end{array}$ & No & No & $\begin{array}{c}\text { Yes } \\
\text { (75 per cent) }\end{array}$ \\
\hline The total vehicle weight subject to payment of tolls & up to $3.5 t$ & from $12 t$ & from $3.5 t$ \\
\hline
\end{tabular}


- there is no uniform categorization of general cargo - the tariffs are set in the Czech Republic only according to the weight of the consignment of $3,000 \mathrm{~kg}$, in Germany and Austria up to $24,000 \mathrm{~kg}$ with different boundary changes of using the vehicle payload,

- average usage of the payload is in the Czech Republic only $8,000 \mathrm{~kg}$ which is consistent with the tariff drafted only to the weight of the consignment of $3,000 \mathrm{~kg}$,

- except for the method of Austria, the continuous utilization of payload of the consignment is not considered in the methodology applied in Germany,

- the vehicle is still not used in terms of payload 100 per cent; therefore, it is necessary to consider the actual usage of the vehicle (e.g. methodology applicable in Austria) methodology applicable in Germany and in the Czech Republic is considered 100 per cent utilization of the vehicle,

- methods applicable in Germany and Austria do not take into account the opportunity to charge different rates for different categories of roads and also do not take into account the allotment of journeys made on the charged roads: the methods consider that any travelled kilometre is realized on the charged road network,

- none of the methods takes into account the possibility of charging time-different rates of the selected roads.

\section{PROPOSAL FOR UNIFORM PROCEDURE FOR DETERMINING TOLL RATES FOR THE TRANSPORTATION OF GENERAL CARGO}

The purpose of the proposed methodology is primarily the application in any state, which charge the usage of the road network through toll and therefore it must respect any distribution of rates in terms of the structure of used vehicles and also a time limit of the rates in each country.

On the basis of the analysis of methodologies of using the charged roads, I propose for assessing the impact of tolls on the transport of general cargo the application of the following procedure:

- Determination of the partial rate of charging of a particular road category of the road network - for each charged category of a road network and in case in which each day of the week has different rates, as well as separately for each day, it is necessary to determine the rate according to equation (5). On the basis of this equation we get as many of partial rates as categories of a road network are charged. For instance, in Slovakia highways and motorways are charged with one rate and the selected roads of Class I are charged with another toll rate, which means that there would be two par- tial rates. In the Czech Republic there are also two types of charged roads - highways and motorways, but with special rates during a special time at the end of the week. It means that there would be four partial rates in the Czech Republic (for highways in the ordinary period, for highways on Fridays from 3 p.m. to 9 p.m., for the selected road of Class I in the period and for the selected road of Class I on Fridays from 3 p.m. to 9 p.m.). In case of tariffs applicable to all the charged roads in the same amount there would be only one partial rate. Seeing that equation (5) is adjusted for the allotment of the travelled distance on roads of a single category, partial rate is a part of the overall average rate.

$S_{j}=\sum_{i=1}^{n}\left(j_{S_{i}} \cdot v_{i}\right) \cdot d_{j}$

$S_{j}$ - average toll rate for $j$ - type of road network (e.g. highway, motorways, roads of Class I, etc.),

$j_{S_{i}}$ - toll rate for the $j$ - type of road network, especially for $i$ - type of vehicle of a carrier,

$v_{i}$ - allotment of the $i$-th kind of fleet of a carrier percentage,

$i$ - dependence of a vehicle on factors that affect the toll rates for specific vehicle (e.g. Dependence on emission standards Euro, the number of axles, etc.),

$d_{j}$ - percentage share of driving performance of vehicles, which carry general cargo passed after $j$-th type of a road network of the overall driving performance

- Determination of the average rate of charging a particular category of roads of the road network the average toll rate in a certain area is determined as the sum of all partial rates, according to equation (5). The average rate in equation (6) is designated as $S_{p}$.

$$
S_{P}=\sum_{j=1}^{m}\left(S_{j}\right)
$$

The proposed methodology within the study [7] has been applied to the conditions of Slovakia. The analysis of the fleet used for transportation of general cargo in Slovakia by members of the Zväz logistiky a zasielatel'stva SR (Association of Logistics and Freight Forwarding of the Slovak Republic) found the allotment of vehicles listed in Table 6. The highest allotment of vehicles is in the weight range from 3.5 to $12 \mathrm{t}$ with an engine which meets the Euro III emission Class (44 per cent).

In terms of allotments of roads used for distribution of general cargo the following allotments of used road network can be made on the basis of the analysis prepared in [7], which is needed for the determination of the allotment of costs for individual transported general cargo: 
Table 6 - The structure of the fleet of analyzed carriers in Slovakia in percentages

\begin{tabular}{|c|c|c|c|c|}
\hline \multicolumn{2}{|c|}{ Vehicle category } & EURO 0 - II (per cent) & EURO III (per cent) & EURO IV, V, EEV (per cent) \\
\hline \multicolumn{2}{|l|}{$3.5 t-$ to $12 t$} & 18 & 44 & 10 \\
\hline \multirow[t]{4}{*}{$12 t$ and more } & -2 axles & 0 & 3 & 0 \\
\hline & - 3 axles & 0 & 1 & 0 \\
\hline & -4 axles & 0 & 1 & 3 \\
\hline & - 5 axles & 6 & 11 & 3 \\
\hline
\end{tabular}

Source: prepared by the author on the basis of [7]

- 32 per cent of travelled distance on motorways and highways,

- 25 per cent of travelled distance on charged roads of Class I,

- 43 per cent of travelled distance on the notcharged road network.

On the basis of the analysis it can be concluded that in the Slovak Republic 43 per cent of the driving performance on not-charged roads is realized. Methodologies used in Austria and Germany do not take this fact into account and in applying of these methodologies in case of pricing of transported general cargo the toll extra fee would be calculated for driving the distance which is travelled on uncharged roads.

- Determination of the average rate to take into account the usage of the fleet - the fact that the carrier must bear the fee for using the road network for the vehicle regardless of whether the cargo is transported, or whether the road network is used without the cargo ${ }^{11}$. And there are routes of transportation, for which the return capacity utilization of the vehicle ${ }^{12}$ is not possible. The average rate of the charge for using of road network for particular transported packages should be increased by the fee for using the road network for driving an empty vehicle. It is also necessary to increase the average fee by the unused loading area of the vehicle, which cannot be used in the order of quantities in the region. The process of increasing the final rates is treated in detail in [8]. The degree of capacity utilization of the vehicle is expressed with a coefficient of payload utilization of the vehicle $\gamma$ [9]. On the basis of this coefficient the average rate, which takes into account the utilization of the fleet ${ }^{\gamma} S_{P}$ by equation (7), can be determined.

$$
{ }^{\gamma} S_{P}=\frac{S_{P}}{\gamma}
$$

The payload utilization of the fleet has not been applied in the methodology used in Germany and in the Czech Republic. In this case it means that it is considered that for each drive the vehicle is used in terms of capacity of 100 per cent and it will not make any journey without cargo. In practice this cannot be achieved and on the basis of an analysis prepared in [7] it can be concluded that the capacity utilization of vehicles reached the level of 5570 per cent (coefficient of payload utilization from 0.55 to 0.7 ).

- Proposal of development of the tariff - for the analysis of methodologies used abroad it can be stated that there is no uniform tariff structure for taking the toll into the price of transport of packages. The differences are both in comparison of distribution of tariff bands and in tariff grades. In developing the proposed rates should be uniform:

- distribution of tariff distance - the distribution of travelled distance into the various tariff bands,

- distribution of tariff grades - the distribution of weight of the carried consignment into the single weight bands.

Specifically, rates $S_{i j}$ of tariff setting addition of the toll by the transport of packages will be determined by equation (8). The rate must be dependent on the actual travelled transport distance and on the weight of the transported consignment. The product of the average rate taking into account the utilization of payload of the vehicle and tariff distance (centre of the tariff zone) is called the average cost of a toll for the transported vehicle. In order to determine the allotment of toll on specific general cargo, it is necessary to calculate the allotment of the total toll to the base value of the vehicle payload.

$S_{i j}=\frac{{ }^{\gamma} S_{P} \cdot l_{i}}{M} \cdot m_{j}$

$S_{i j}$ - specific rate of the tariff for the $i$-th tariff band and $j$-th tariff grade,

$l_{i}$ - distance of $i$-th tariff zone,

$m_{j}-j$-th tariff grade,

M - payload of the vehicle.

According to the analysis prepared in [6] and in other materials ${ }^{13}$ it can be concluded that in the transport of individual packages the vehicles with the next payload $(M)$ are used:

- For consignments up to the weight of 3,000kg vehicles are used with an average payload of $8,000 \mathrm{~kg}$,

- For consignments from the weight of 3,000kg vehicles are used with an average payload of 12,000kg, 
By the proposed setting of rates an unwanted fact occurs: that by comparing of two consecutive consignments of up to $3,000 \mathrm{~kg}$ and over $3,000 \mathrm{~kg}$, that are carried on the same transport distance, this reduces the rate of the toll addition by the changes of the vehicle payload. For the customer it does not matter by what means of transport the transportation is realized; hence the requirement that the rate may not decrease with increasing weight. The problem can be resolved by the procedure that is implemented in the methodology used in Austria. It means that in the specific interval of weight change of transported consignment, when the vehicle payload capacity is changeable, fluent vehicle payload capacity increase can be used. The proposal for allocation of the average payload of vehicles used for specific consignment weights are listed in Table 7. For the transportation of the package with a weight of over $12,000 \mathrm{~kg}$ the fact should be considered that in practice the consignment is usually carried as a full truck load. It means that there is only one item carried in the vehicle. In this case there is no need of toll from the transportation to calculate several consignments and it can be set directly to a specific consignment based on equation (9) like the product of the average rate, that takes into account the usage of payload of the vehicle and diameter of the $i$-th tariff band of the transportation of general cargo.

$$
S_{i}={ }^{\gamma} S_{P} \cdot l_{i}
$$

Table 7 - Proposal for allocation of the average payload of the vehicle depending on the weight of the consignment

\begin{tabular}{|c|c|}
\hline $\begin{array}{c}\text { Weight of the con- } \\
\text { signment (kg) }\end{array}$ & $\begin{array}{c}\text { Capacity utilization } \\
\text { of the vehicle }(\mathrm{kg})\end{array}$ \\
\hline \hline $2,250-2,500$ & 8,000 \\
\hline $2,500-2,750$ & 8,800 \\
\hline $2,750-3,000$ & 9,600 \\
\hline $3,000-3,500$ & 10,400 \\
\hline $3,500-4,000$ & 11,200 \\
\hline $4,000-4,500$ & 12,000 \\
\hline
\end{tabular}

Source: the author [6]

\section{CONCLUSION}

The establishment of fair road network charging by toll increases the costs of the carrier. This toll depends on the number of travelled charged kilometres. In any case, it is not possible to cover the increased costs from the carrier's own reserve. Therefore it is important to search for the ways of fair transfer of charges to customers. This requirement is valid also in the case of general cargo.

Gradually, in certain states there are many ways of how to implement the increased costs into the price for transportation. Nowadays, there are many methods of increased costs implementation in some states (Austria, Germany and Czech Republic). However, these methods cannot be used in other states without modification.

The proposed method of increased costs implementation into the price of general cargo transportation is applicable in any known toll system. This method was established in conditions of Slovakia. It can be also applied without modification in establishing the system in Poland and preparing the system in Hungary. The advantage of this method is the possibility of its application to many toll systems. It means that in price setting the carrier works with just one method also in international freight transport.

In case of road network charging by toll stickers, the carriers did not use any method. The cost of time was included into fixed costs. Therefore, the method is particularly beneficial for the carriers to change the pricing of the road network. In comparison with the existing methods abroad, the benefit of this method is its possibility of application to the charging system with various tariffs, which is not the case with the several methods used in Western Europe. The method also considers the utilization of the vehicle. This fact is not considered in the analysed methods.

The advantage of the method is more accurate and more righteous determination of costs for the realised performances.

MILOŠ POLIAK, Ph.D.

E-mail: milos.poliak@fpedas.uniza.sk

Žilinská univerzita,

Fakulta prevádzky a ekonomiky dopravy a spojov Univerzitná 1, 01026 Žilina, Slovenská republika

\section{ABSTRAKT}

\section{VPLYV SPOPLATNENIA CESTNEJ SIETE NA TVORBU CENY PRI PREPRAVE KUSOVÝCH ZÁSIELOK}

Príspevok v prvej časti definuje problém cenotvorby pri preprave kusových zásielok vplyvom mýta. Rôzne využitie vozidla pri jednotlivých prepravách spôsobuje, že nie je možné rozpočitavat' mýto jednotne na všetky zásielky pri udržaní konštantnej ceny pre zákazníka pri rovnakej preprave. $\checkmark$ d'alšej časti je spracovaná analýza existujúcich postupov stanovenia podielu mýta na kusovú zásielku v Rakúsku, Česku a Nemecku. Ani jeden postup nie je možné univerzálne použit pre ostatný štát. V ostatnej časti je spracovaný návrh novej metodiky stanovenia podielu mýta na kusovú zásielku.

\section{KL'ÚČOVÉ SLOVÁ}

preprava, cenotvorba, zásielka, mýto, cesta

\section{REFERENCES}

1. Data published on www.e-myto.sk 
2. The analysis published in [12]

3. For example, the results published in [13]

4. Based on information available at: www.go-maut.at

5. Based on Directive 1999/62/EC of the European Parliament and of the Council on the charging of heavy goods vehicles for the use of certain infrastructures

6. prepared on the basis of materials published on the website: www.tollcollect.de

7. prepared on the basis of Mautgebühren für den Spediteursammelgutverkehr, Vereinigung der Sammelguspediteure im BSL, 2003, Bonn

8. 1 Lademeter $=$ includes 1 meter storage truck along the length $=1 \mathrm{~m} \times 2.4 \mathrm{~m}$ width $\times 2.4 \mathrm{~m}$ height $=5.76 \mathrm{~m}^{3}$

9. prepared on the basis of Mautgebühren für den Spediteursammelgutverkehr, Vereinigung der Sammelguspediteure im BSL, 2003, Bonn

10. Prepared on the basis of materials published on the website: www.premid.cz

11. E.g. by www.e-myto.sk

12. E.g. according to analysis published in the weekly newspaper Dopravní noviny No. 24/2010 (R 6063 - 46 $325 \mathrm{MIC}$ ) for some regions in international traffic, there is the return capacity utilization of the vehicle at the level of 15 per cent of vehicles

13. For example: Mautgebühren für den Spediteursammelgutverkehr, Vereinigung der Sammelguspediteure im BSL, 2003, Bonn

\section{LITERATURE}

[1] Poliak, M. - Konečný, V. (2008): "Faktory determinujúce rozsah spoplatnenia cestnej infraštruktúry elektronickým mýtom", Journal of Economics, 7/56/2008, 712 - 731
[2] Lowe, D. (2005): Intermodal Freight Transport, Typeset by Charon tec Pvt. Ltd, Chennai

[3] Cempírek, V. et al. (2007): Metodika stanovení sazeb v silnični nákladni dopravě na území České republiky po zavedeni elektronického mýta, University of Pardubice, Pardubice

[4] Nijkamp, P. (2004): Transport Systems and policy Selected Essays of Peter Nijkamp - Volume 2; Edward Elgar Publishing Limited, Gheltenham

[5] Kotler, Ph. and Wong, V. and Saunders, J. (2007): Moderni marketing, Granada, Praha

[6] Kummer, S. (2003): Die österreichische LKW-maut - Gutachten und Kalkulations - Tabellen; Bohmann Druck und Verlag Ges.m.b.H. \& CO.KG., Wien

[7] Gnap, J. and Poliak, M. (2009): Metodika pre stanovenie sadzieb pri preprave kusových zásielok na území SR po zavedení elektronického mýta; University of Žilina, Žilina

[8] Gnap, J. (2002): Kalkulácia vlastných nákladov a tvorba ceny $v$ cestnej doprave; University of Žilina; Žilina

[9] Královenský, J. et al. (2008): Ekonomika cestnej a mestskej dopravy 1; University of Žilina, Žilina

[10] Poliak, M. (2009): "Impacts of toll collection introduction on haulers", Transcom $2009-8^{\text {th }}$ European conference of young research and scientific workers - Žilina June 22-24, 2009, Žilina, 69 - 72.

[11] Poliak, M. (2010): "Dosah mýta na náklady dopravcu", Doprava a logistika, 5-2010, 21

[12] Poliak, M. (2008): "Zavedenie elektronického mýta v SR z pohl'adu cestného dopravcu"; Medzinárodná konferencia ITS Bratislava 08; 56 - 68

[13] Gnap, J. and Konečný, V. and Poliak, M. (2006): “Elasticita dopytu v hromadnej osobnej deprave", Journal of Economics, 7/54/2006, 668 - 684 